\title{
Yoghurt in the Spanish diet: nutritional implications and socio-cultural aspects of its consumption
}

\author{
Francesca Capdevila $^{1, *}$, Carles Martí-Henneberg ${ }^{\top} \dagger$, Ricardo Closa ${ }^{1}$, \\ Joaquín Escribano Subías ${ }^{1}$ and Joan Fernández-Ballart ${ }^{2}$ \\ 'Pediatrics Unit, Research Group on Food, Nutrition, Growth and Mental Health, Faculty of Medicine, University \\ Rovira i Virgili, C/ Sant Llorenç 21, 43201 Reus, Spain: ${ }^{2}$ Preventive Medicine Unit, Research Group on Food, \\ Nutrition, Growth and Mental Health, Faculty of Medicine, University Rovira i Virgili, Reus, Spain
}

Submitted 9 May 2002: Accepted 14 November 2002

\begin{abstract}
Objectives: This study aims to analyse the differences, with regard to socio-cultural characteristics and dietary habits, between low and high consumers of yoghurt and other fermented dairy product desserts, and the nutritional significance of these differences.

Methods: We analysed the diet of a healthy population (4-65 years), using the 24-hour recall method, on three non-consecutive days. The participants were grouped by age and sex and were also divided into tertiles on the basis of yoghurt consumption. We compared energy and nutrient intakes, educational level and socio-economic status in the low consumption (LC) group and the high consumption (HC) group.

Results: In general there were no significant differences in energy intake or nutritional profile between LC and HC groups. The only significant difference was in the percentage of energy provided by lipids, which was significantly lower in HC women, possibly due to the high number of women in this group who consumed low-fat yoghurt. There were significant differences in the distribution of HC and LC subjects according to the three educational levels $(P<0.05)$, but not according to socioeconomic status.

Conclusion: The fact of being a high consumer of fermented dairy products took place in the framework of other dietary changes that compensated for this high consumption, resulting in the absence of significant differences in energy intake and nutritional profile between HC and LC subjects. The only exception was found in women who consumed low-fat dairy products. There was a relationship between high consumption of fermented dairy products and educational level.
\end{abstract}

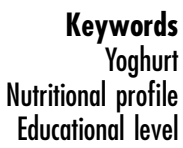

Despite the fact that consumption of dairy products in Spain is moderate in comparison with other areas of Europe, in recent years the figure has risen considerably ${ }^{1-4}$. This increase is due not only to the fact that the dairy industry continually develops and markets a wide range of new products ${ }^{5,6}$, but also because there has been a major change in the qualitative concept of the term 'diet'. Diet is no longer seen simply as a source of energy and nutrients to satisfy the needs of the individual, but a means by which health can be improved ${ }^{7}$. In this respect, dairy products have acquired considerable importance in several different areas.

First, they are the main provider of dietary calcium, essential for bone density and the prevention of osteoporosis $^{8-10}$, and also for the prevention of obesity,

†Deceased. as in recent years different studies have demonstrated that increasing calcium intake may protect against obesity $^{11-13}$. Fermented dairy products are also rich in other nutrients such as proteins of high biological value; other highly bioavailable minerals such as phosphorus, potassium and zinc; and vitamins, especially vitamins $B_{2}$ and $\mathrm{B}_{12}$, which in these foods are highly bioavailable ${ }^{8}$. Furthermore, over the last two decades several studies have furnished evidence supporting the blood pressurelowering effects of dairy products ${ }^{14,15}$. One of the most relevant works in this field is the DASH (Dietary Approaches to Stop Hypertension) Study, which analysed the impact on blood pressure of three different diets. A diet rich in low-fat dairy products, fruit and vegetables was found to be the combination that reduced blood pressure most, both in hypertensive and non-hypertensive subjects ${ }^{15,16}$ 
In addition to the above cited benefits of dairy products, and due to technological advances in this sector, there is now a wide range of low-fat dairy products that can satisfy the demand of a consumer population increasingly concerned with the issue of obesity and low-energy $\operatorname{diets}^{17}$.

But, apart from their nutritional value, fermented dairy products have made further headway in the market because they are functional foods; that is to say, they have a proven beneficial effect on one or more specific functions in humans ${ }^{7,18-20}$. Although in the future other foods may contain probiotics such as Lactobacillus and Bifidobacterium spp., fermented dairy products are currently the most common source ${ }^{21,22}$.

The aims of this paper are to study the nutritional implications of high consumption of yoghurt and other similar fermented dairy products, and to establish whether this high consumption is linked to other changes in the diet. In particular, we analyse the subgroup of consumers of low-fat yoghurts in an attempt to determine the effect of this dietary behaviour on diet, energy density (ED), the volume of intake and nutritional profile. The paper also aims to determine whether there is a relationship between the consumption of these fermented dairy products and socio-economic or educational level.

\section{Materials and methods}

This study was conducted in 1999, in Reus (Spain). The sample was randomly selected from the population census. The central unit was the family and the families selected were representative of all sectors of the city and of the distinct socio-economic levels. We studied 773 individuals with an age range from 4 to 65 years. The sample was divided into groups according to age and sex.

To assess the intakes of food and nutrients, we used the 24-hour recall method on three non-consecutive days, one of which was always a non-working day. This method has been shown to provide accurate estimates for population groups $^{23}$. In each case, we interviewed the participant and the person responsible for preparing meals.

To help determine the quantities ingested, we showed interviewees a set of photographs of types of food. To assess items such as oil, we consulted a table containing standardised values of the quantities used in certain dishes as a reference value.

Four interviewers collected the data at participants' homes. All four interviewers had undergone a period of training and standardisation before the study began. Likewise, after approximately one-third of the study, we analysed the homogeneity of the interviewers' data collection styles via a statistical comparison of their recordings of the intakes of certain food groups (those that were considered the most difficult to assess, such as oil and added fats) in five individuals. No significant inter-rater differences were found using an analysis of the variance.

The French food composition table ${ }^{24}$ was used to convert food into nutrients. Data on food that did not appear in that table (basically, typical Spanish dishes) were provided by the table from Mataix-Verdú et $a .^{25}$.

The population, previously grouped by age and sex, was then divided into tertiles according to consumption of yoghurt and other fermented dairy products: the lowest tertile being the group of non- and low consumers (LC), the middle being the group of medium consumers (MC) and the highest tertile corresponding to the group of high consumers (HC). We later compared the low and high tertiles (LC and HC) in order to obtain groups with more extreme differences and thus determine clearly the nutritional impact of consuming yoghurt and similar fermented dairy products.

As well as the food survey, the participants answered a questionnaire about their education and their professional activity, in order to determine whether there was a relationship between the intake of dairy products and these variables. Educational level was assessed by asking about the level of studies achieved. We grouped these categories into three levels: low (those with incomplete compulsory schooling, or those with the highest level of education being 'General basic education'), medium (those with the highest level of education being 'Unified polyvalent general upper secondary education', 'University guidance course' or 'Professional training') and high (those with university studies, doctorate or post-degree studies).

The socio-economic status was assessed by asking about profession and professional level (inactive, nonskilled worker, skilled worker, administrative, sales manager, director, etc.) and then combining this information to obtain three categories: low, medium and high.

For the statistical analysis we used the statistical package SPSS 10.0 for Windows ${ }^{26}$. To compare the differences between the levels of consumption we used Student's $t$-test. The significance level for all of the two-tailed tests was set at $P<0.05$. Regression analyses were carried out to analyse the trends related to age. To compare the percentages of the population in each socio-economic and educational level we used the chi-square test.

\section{Results}

Table 1 compares yoghurt consumption $\left(\mathrm{g} \mathrm{day}^{-1}\right)$, and also the intakes of protein $\left(\mathrm{g} \mathrm{day}^{-1}\right)$, lipids $\left(\mathrm{g} \mathrm{day}^{-1}\right)$ and carbohydrates $\left(\mathrm{g} \mathrm{day}^{-1}\right)$, between low and high consumers of yoghurt, grouping the individuals by age and sex. In all age groups there were significant differences regarding the intake of yoghurt between high and low consumers. But the only group where we found significant differences in macronutrient intakes was in men aged 20-34 years, in which the higher consumers had 
Table 1 Intakes $\left(\mathrm{g} \mathrm{day}^{-1}\right.$ ) of yoghurt, protein, lipids and carbohydrates: comparison between low consumers (LC) and high consumers (HC) of yoghurt

\begin{tabular}{|c|c|c|c|c|c|c|c|c|}
\hline & \multicolumn{2}{|c|}{ Yoghurt (g day ${ }^{-1}$ ) } & \multicolumn{2}{|c|}{ Protein $\left(\right.$ g day $\left.^{-1}\right)$} & \multicolumn{2}{|c|}{ Lipids $\left(\mathrm{g} \mathrm{day}^{-1}\right.$ ) } & \multicolumn{2}{|c|}{ Carbohydrates $\left(\right.$ g day $^{-1}$ ) } \\
\hline & LC & $\mathrm{HC}$ & LC & $\mathrm{HC}$ & LC & $\mathrm{HC}$ & LC & $\mathrm{HC}$ \\
\hline \multicolumn{9}{|l|}{$4-9$ years } \\
\hline Boys $(26 / 17) \dagger$ & $26.2 \pm 32.4$ & $148.8 \pm 45.2^{\star \star \star}$ & $77.7 \pm 23.0$ & $81.9 \pm 11.4$ & $98.1 \pm 23.8$ & $102.8 \pm 14.5$ & $239.3 \pm 58.9$ & $238.9 \pm 39.6$ \\
\hline Girls (20/18) & $24.2 \pm 31.1$ & $163.1 \pm 81.0^{\star \star \star}$ & $80.4 \pm 13.7$ & $75.6 \pm 14.9$ & $101.4 \pm 25.4$ & $95.7 \pm 16.7$ & $229.3 \pm 61.0$ & $245.8 \pm 45.3$ \\
\hline \multicolumn{9}{|l|}{$10-19$ years } \\
\hline Boys (27/32) & $23.9 \pm 26.8$ & $142.8 \pm 72.6^{\star \star \star}$ & $100.1 \pm 33.1$ & $97.0 \pm 19.2$ & $126.7 \pm 42.1$ & $118.2 \pm 31.3$ & $292.7 \pm 98.5$ & $272.2 \pm 66.9$ \\
\hline Girls (32/29) & $21.2 \pm 24.9$ & $144.4 \pm 79.2^{\star \star \star}$ & $77.9 \pm 22.9$ & $82.5 \pm 19.3$ & $96.8 \pm 28.0$ & $92.0 \pm 24.4$ & $192.1 \pm 58.1$ & $212.2 \pm 52.8$ \\
\hline \multicolumn{9}{|l|}{ 20-34 years } \\
\hline Men (26/27) & $22.6 \pm 27.5$ & $161.1 \pm 131.1^{\star \star \star}$ & $91.2 \pm 29.4$ & $113.6 \pm 25.0^{\star *}$ & $105.3 \pm 35.8$ & $138.5 \pm 42.0^{\star *}$ & $204.5 \pm 53.0$ & $283.7 \pm 79.6^{\star \star}$ \\
\hline Women (29/27) & $17.8 \pm 22.3$ & $129.6 \pm 46.3^{\star \star \star}$ & $71.6 \pm 18.9$ & $82.3 \pm 26.9$ & $80.9 \pm 25.4$ & $85.8 \pm 29.1$ & $174.7 \pm 49.0$ & $193.9 \pm 59.7$ \\
\hline \multicolumn{9}{|c|}{$35-50$ years } \\
\hline Men $(35 / 29)$ & $13.0 \pm 17.5$ & $111.4 \pm 55.5^{\star \star \star}$ & $92.1 \pm 21.9$ & $98.5 \pm 24.4$ & $107.7 \pm 26.8$ & $116.9 \pm 33.3$ & $237.8 \pm 70.2$ & $247.5 \pm 62.8$ \\
\hline Women $(49 / 45)$ & $8.8 \pm 16.1$ & $118.8 \pm 85.2^{\star \star *}$ & $73.2 \pm 21.0$ & $74.5 \pm 21.1$ & $80.0 \pm 26.1$ & $77.4 \pm 22.9$ & $172.4 \pm 60.2$ & $165.6 \pm 55.3$ \\
\hline \multicolumn{9}{|l|}{$51-65$ years } \\
\hline Men (27/24) & $17.1 \pm 24.6$ & $149.1 \pm 67.3^{\star \star \star}$ & $82.1 \pm 21.2$ & $92.9 \pm 28.5$ & $85.9 \pm 22.3$ & $105.3 \pm 40.3$ & $187.8 \pm 44.7$ & $217.0 \pm 60.1$ \\
\hline Women $(26 / 27)$ & $23.0 \pm 24.7$ & $161.1 \pm 83.0^{\star \star \star}$ & $92.9 \pm 28.5$ & $88.7 \pm 17.2$ & $74.3 \pm 29.1$ & $69.6 \pm 24.3$ & $162.5 \pm 49.6$ & $170.5 \pm 41.8$ \\
\hline
\end{tabular}

Mean \pm standard deviation.

${ }^{\star \star}, P<0.01 ;{ }^{\star \star \star}, P<0.001$ with respect to low consumers

$+n \mathrm{LC} / n \mathrm{HC}$

significantly greater intakes of protein, lipids and carbohydrates.

Table 2 compares the intakes of calcium, potassium, phosphorus and vitamin $\mathrm{B}_{2}$ between low and high consumers of yoghurt. In the group of men aged 20-34 years, the intakes of these micronutrients were significantly greater in high consumers of yoghurt than in low consumers. In boys aged 4-9 years the consumption of calcium and vitamin $\mathrm{B}_{2}$ was also greater in high consumers compared with low consumers. No significant differences were observed between LC and HC in the other groups.

Table 3 shows the differences regarding energy intake $\left(\mathrm{kcalday}^{-1}\right)$, food intake $\left(\mathrm{g} \mathrm{day}^{-1}\right)$ and $\operatorname{ED~}\left(\mathrm{kcalg}^{-1}\right)$ of the diet between HC and LC groups. The statistical analysis again showed that men aged $20-34$ years in the HC group had greater energy and food intakes than the lower consumers, while intakes in the rest of the age groups analysed were similar. The differences between sexes were maintained.

Figures 1 and 2 compare the percentages of total energy provided by each macronutrient, between the two levels of yoghurt consumption in men (Fig. 1) and women (Fig. 2). There were no significant differences in men, but there was a significant difference in the percentage of energy provided by lipids in women: in low consumers of yoghurt this percentage was $42.4 \%$, compared with $40.9 \%$

Table 2 Intakes $\left(\mathrm{mg} \mathrm{day}^{-1}\right)$ of calcium, potassium, phosphorus and vitamin $\mathrm{B}_{2}$ : comparison between low consumers (LC) and high consumers $(\mathrm{HC})$ of yoghurt

\begin{tabular}{|c|c|c|c|c|c|c|c|c|}
\hline & \multicolumn{2}{|c|}{$\begin{array}{c}\text { Calcium } \\
\left(\mathrm{mg} \mathrm{day}^{-1}\right)\end{array}$} & \multicolumn{2}{|c|}{$\begin{array}{l}\text { Potassium } \\
\left(\mathrm{mg} \mathrm{day}^{-1}\right)\end{array}$} & \multicolumn{2}{|c|}{$\begin{array}{l}\text { Phosphorus } \\
\left(\mathrm{mg} \mathrm{day}^{-1}\right)\end{array}$} & \multicolumn{2}{|c|}{$\begin{array}{l}\text { Vitamin } B_{2} \\
\left(\text { mg day }^{-1}\right)\end{array}$} \\
\hline & LC & $\mathrm{HC}$ & LC & $\mathrm{HC}$ & LC & $\mathrm{HC}$ & LC & $\mathrm{HC}$ \\
\hline \multicolumn{9}{|l|}{$4-9$ years } \\
\hline Boys $(26 / 17) \dagger$ & $667.9 \pm 220.1$ & $810.1 \pm 151.4^{*}$ & $2391.9 \pm 464.1$ & $2528.7 \pm 340.1$ & $1149.9 \pm 309.6$ & $1312.9 \pm 261.9$ & $1.5 \pm 0.3$ & $1.8 \pm 0.4^{*}$ \\
\hline Girls $(20 / 18)$ & $641.0 \pm 213.8$ & $684.6 \pm 216.2$ & $2133.1 \pm 412.8$ & $2439.8 \pm 687.6$ & $1231.8 \pm 243.0$ & $1183.8 \pm 345.5$ & $1.4 \pm 0.3$ & $1.4 \pm 0.4$ \\
\hline \multicolumn{9}{|l|}{$10-19$ years } \\
\hline Boys (27/32) & $802.9 \pm 391.1$ & $726.0 \pm 271.5$ & $2765.1 \pm 1144.9$ & $2736.6 \pm 666.1$ & $1526.5 \pm 580.5$ & $1477.7 \pm 469.7$ & $1.8 \pm 0.7$ & $1.8 \pm 0.5$ \\
\hline Girls (32/29) & $573.9 \pm 296.4$ & $661.1 \pm 231.9$ & $2184.4 \pm 589.1$ & $2326.9 \pm 573.4$ & $1082.1 \pm 393.1$ & $1168.2 \pm 435.5$ & $1.4 \pm 0.5$ & $1.5 \pm 0.4$ \\
\hline \multicolumn{9}{|l|}{$20-34$ years } \\
\hline Men (26/27) & $665.6 \pm 350.7$ & $843.9 \pm 296.7$ & $2497.6 \pm 695.6$ & $3162.1 \pm 925.9^{\star \star}$ & $1165.6 \pm 325.4$ & $1482.9 \pm 331.0^{* \star}$ & $1.6 \pm 0.5$ & $1.9 \pm 0.5^{*}$ \\
\hline Women $(29 / 27)$ & $674.4 \pm 259.1$ & $680.9 \pm 237.6$ & $2139.2 \pm 646.9$ & $2398.7 \pm 789.2$ & $1054.0 \pm 309.7$ & $1104.1 \pm 422.8$ & $1.4 \pm 0.5$ & $1.4 \pm 0.4$ \\
\hline \multicolumn{9}{|c|}{$35-50$ years } \\
\hline Men (35/29) & $661.0 \pm 308.6$ & $762.7 \pm 286.1$ & $3072.8 \pm 872.9$ & $3267.6 \pm 728.2$ & $1249.6 \pm 328.9$ & $1381.1 \pm 311.0$ & $1.7 \pm 0.5$ & $1.8 \pm 0.5$ \\
\hline Women $(49 / 45)$ & $598.9 \pm 276.3$ & $637.1 \pm 245.0$ & $2375.9 \pm 696.6$ & $2362.2 \pm 690.6$ & $995.1 \pm 302.6$ & $1038.2 \pm 305.9$ & $1.4 \pm 0.5$ & $1.4 \pm 0.5$ \\
\hline \multicolumn{9}{|l|}{$51-65$ years } \\
\hline Men $(27 / 24)$ & $487.0 \pm 257.9$ & $617.4 \pm 220.5$ & $2787.1 \pm 685.4$ & $2786.2 \pm 841.3$ & $1053.7 \pm 265.7$ & $1167.1 \pm 315.6$ & $1.4 \pm 0.5$ & $1.6 \pm 0.3$ \\
\hline Women $(26 / 27)$ & $581.5 \pm 259.5$ & $643.8 \pm 287.8$ & $2451.3 \pm 718.6$ & $2669.4 \pm 648.4$ & $976.2 \pm 283.8$ & $961.9 \pm 290.8$ & $1.4 \pm 0.5$ & $1.5 \pm 0.4$ \\
\hline
\end{tabular}

Mean \pm standard deviation.

${ }^{\star}, P<0.05 ;{ }^{* \star}, P<0.01$ with respect to low consumers.

$\dagger n \mathrm{LC} / n \mathrm{HC}$. 
Table 3 Nutritional profile of low consumers (LC) and high consumers (HC) of yoghurt

\begin{tabular}{|c|c|c|c|c|c|c|}
\hline & \multicolumn{2}{|c|}{$\begin{array}{c}\text { Energy intake } \\
\left(\text { kcal day }^{-1}\right)\end{array}$} & \multicolumn{2}{|c|}{$\begin{array}{l}\text { Food intake } \\
\left(\mathrm{g} \mathrm{day}^{-1}\right)\end{array}$} & \multicolumn{2}{|c|}{$\begin{array}{l}\text { Energy density } \\
\quad\left(\mathrm{kcal} \mathrm{g}^{-1}\right)\end{array}$} \\
\hline & LC & $\mathrm{HC}$ & LC & $\mathrm{HC}$ & LC & $\mathrm{HC}$ \\
\hline \multicolumn{7}{|l|}{$4-9$ years } \\
\hline Boys $(26 / 17) \dagger$ & $2166.2 \pm 464.3$ & $2235.5 \pm 222.7$ & $1335.3 \pm 260.4$ & $1418.0 \pm 160.5$ & $1.6 \pm 0.3$ & $1.6 \pm 0.2$ \\
\hline Girls (20/18) & $2168.5 \pm 435.2$ & $2173.3 \pm 338.3$ & $1256.7 \pm 227.0$ & $1300.7 \pm 293.1$ & $1.7 \pm 0.3$ & $1.7 \pm 0.3$ \\
\hline \multicolumn{7}{|l|}{$10-19$ years } \\
\hline Boys $(27 / 32)$ & $2733.5 \pm 860.9$ & $2571.3 \pm 541.7$ & $1512.2 \pm 494.9$ & $1511.9 \pm 276.3$ & $1.8 \pm 0.2$ & $1.7 \pm 0.2$ \\
\hline Girls $(32 / 29)$ & $1982.5 \pm 518.8$ & $2019.7 \pm 436.2$ & $1181.8 \pm 305.3$ & $1303.1 \pm 276.8$ & $1.7 \pm 0.3$ & $1.6 \pm 0.3$ \\
\hline \multicolumn{7}{|l|}{$20-34$ years } \\
\hline Men $(26 / 27)$ & $2201.9 \pm 565.3$ & $2891.0 \pm 701.5^{\star \star \star}$ & $1404.2 \pm 396.3$ & $1719.0 \pm 442.6^{*}$ & $1.6 \pm 0.3$ & $1.7 \pm 0.2$ \\
\hline Women $(29 / 27)$ & $1754.5 \pm 443.7$ & $1907.6 \pm 525.8$ & $1174.9 \pm 292.1$ & $1343.6 \pm 336.2$ & $1.5 \pm 0.2$ & $1.4 \pm 0.2$ \\
\hline \multicolumn{7}{|l|}{$35-50$ years } \\
\hline Men (35/29) & $2419.1 \pm 534.3$ & $2560.2 \pm 635.7$ & $1742.9 \pm 477.9$ & $1732.1 \pm 466.8$ & $1.4 \pm 0.2$ & $1.5 \pm 0.2$ \\
\hline Women $(49 / 45)$ & $1758.4 \pm 493.6$ & $1708.0 \pm 441.5$ & $1326.0 \pm 366.4$ & $1379.9 \pm 379.4$ & $1.4 \pm 0.3$ & $1.3 \pm 0.2$ \\
\hline \multicolumn{7}{|l|}{$51-65$ years } \\
\hline Men (27/24) & $2005.3 \pm 406.1$ & $2308.0 \pm 652.2$ & $1485.8 \pm 346.3$ & $1623.4 \pm 496.7$ & $1.4 \pm 0.2$ & $1.4 \pm 0.2$ \\
\hline Women (26/27) & $2308.0 \pm 652.2$ & $1617.5 \pm 422.9$ & $1294.7 \pm 354.7$ & $1430.8 \pm 311.3$ & $1.3 \pm 0.3$ & $1.1 \pm 0.2$ \\
\hline
\end{tabular}

Mean \pm standard deviation.

*, $P<0.05$; ${ }^{* \star *}, P<0.001$ with respect to low consumers.

$\dagger n \mathrm{LC} / n \mathrm{HC}$.

in high consumers $(P<0.05)$. In order to analyse the reason for this difference, we divided the women in the HC group into low-fat or full-fat yoghurt consumers. Figure 3 shows the differences in the consumption of other food groups between women who were high consumers of full-fat and low-fat yoghurt and other fermented dairy product desserts (the group of 4-9-year-old girls was excluded from this analysis, as there were no consumers of low-fat yoghurt). Low-fat yoghurt consumers ingested less cereals $(P<0.001)$, sugars $(P<0.05)$ and whole milk $(P<0.01)$, and consumed more skimmed milk $(P<$ 0.01 ). We did not observe significant differences in the diet pattern between men low consumers or high consumers of low-fat yoghurt (data not shown).

Table 4 analyses the differences in ED and food intake between the two subgroups of high consumers of dairy products: consumers of full-fat and low-fat products. Among men, the consumers of low-fat yoghurt and desserts had a lower ED $\left(1.5 \mathrm{kcal} \mathrm{g}^{-1}\right.$, vs. $1.6 \mathrm{kcal} \mathrm{g}^{-1}$ for those who consumed full-fat products; $P<0.01)$ but their

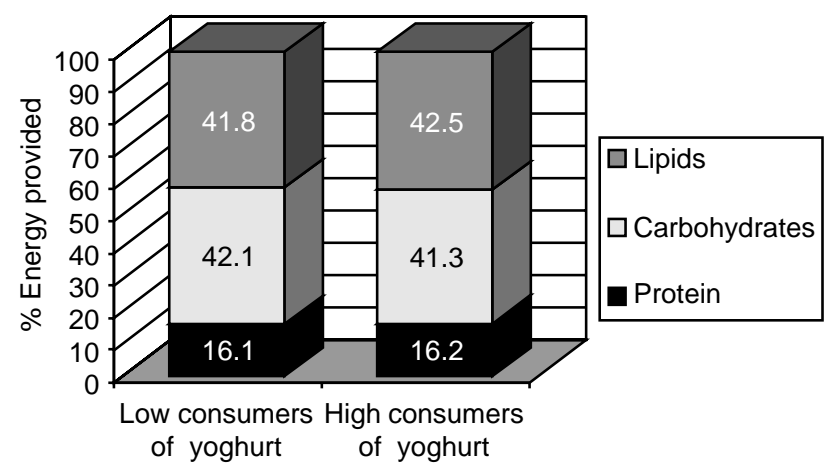

Fig. 1 Macronutrient balance (percentage of total energy provided by each macronutrient) in high and low consumers of yoghurt: men food intake was significantly higher (1749.4 $\mathrm{g} \mathrm{day}^{-1}$, vs. $\left.1570.4 \mathrm{~g} \mathrm{day}^{-1} ; P<0.05\right)$. The energy intake did not differ significantly between the two groups.

Women who consumed low-fat yoghurt had a significantly lower ED $\left(1.2 \mathrm{kcalg}^{-1}\right.$, vs. $1.5 \mathrm{kcalg}^{-1}$ in female consumers of full-fat products; $P<0.01)$. Their food intake, however, was not significantly different, and their energy intake was significantly lower (1634.6 kcal day ${ }^{-1}$, vs. $1926.6 \mathrm{kcal} \mathrm{day}^{-1} ; P<0.01$ ).

The relationship between the consumption of different dairy products and socio-economic and educational variables is shown in Table 5, which presents the percentage of high consumers in each educational and socio-economic level. We only found significant differences in the distribution of the percentage of high and low yoghurt consumers in the three educational levels $(P<0.05)$. These differences were not observed for socio-economic level, or for educational level among high and low consumers of other dairy products such as cheese or milk.

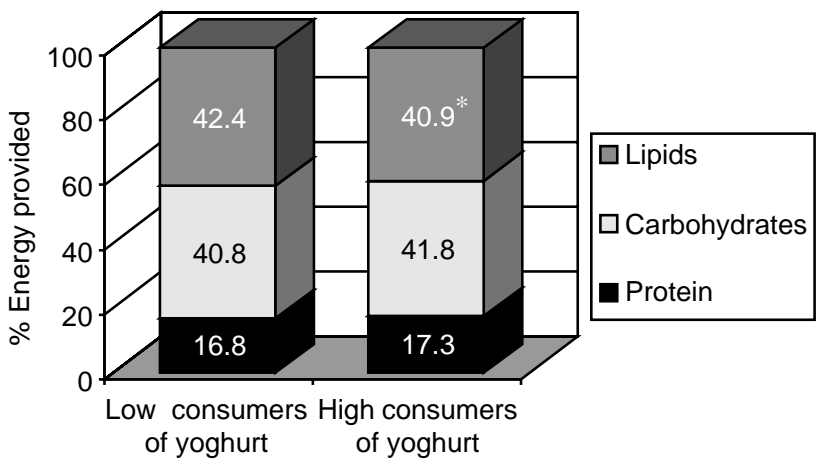

Fig. 2 Macronutrient balance (percentage of total energy provided by each macronutrient) in high and low consumers of yoghurt: women. *, Significant difference in percentage of energy provided by lipids, $P<0.05$ 


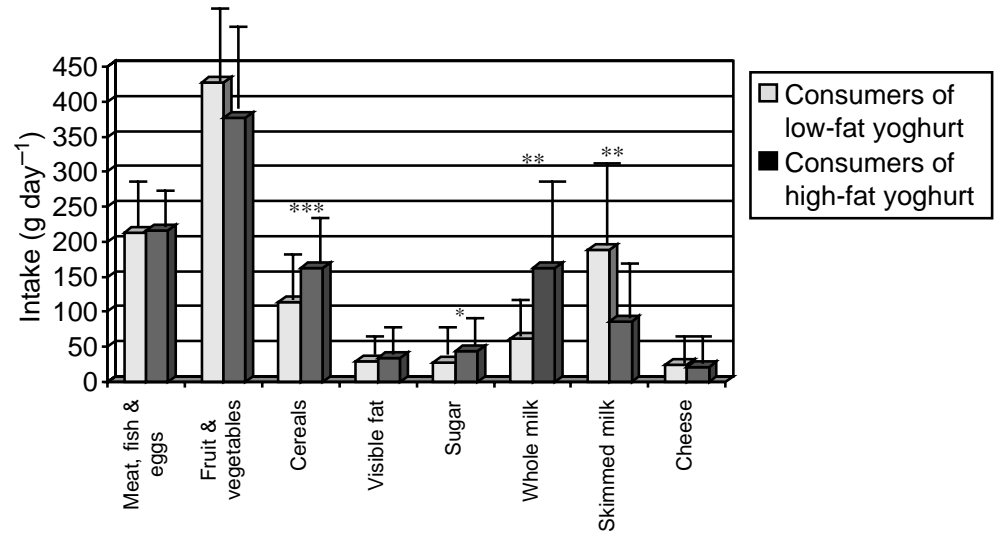

Fig. 3 Food intake of high consumers of whole-fat and low-fat yoghurt: women. Significant difference between groups: ${ }^{*}, P<0.05$; ${ }_{\star \star *}, P<0.01 ;{ }^{* \star *}, P<0.001$

In order to study whether the intake of yoghurt could be related to the consumption of other dairy products, we carried out correlation analyses between the consumption of yoghurt and other dairy products such as milk and cheese. No significant results were obtained.

\section{Discussion}

Yoghurt and similar fermented dairy products are among the food groups that have undergone the greatest increase in consumption over recent decades in our population ${ }^{3,4,6}$. For this reason we sought to analyse to what extent a low or high consumption of these products could be related to nutritional intake.

The results of our study show that there were no significant differences in energy and macronutrient intakes between low and high consumers of yoghurt and similar fermented dairy products, except for the group of men aged 20-34 years.

Intake was always lower in women than in men. In men (in both low and high consumption groups) the maximum intakes of macronutrients were found at 10-34years, followed by a maintenance and then a decrease in the oldest age group. In women the pattern of macronutrients was different.

Table 4 Nutritional profile of consumers of low-fat and full-fat yoghurts, within the group of high consumers of yoghurt

\begin{tabular}{|c|c|c|c|}
\hline & $\begin{array}{c}\text { Energy } \\
\text { intake } \\
\left(\text { kcal day }^{-1}\right)\end{array}$ & $\begin{array}{l}\text { Food intake } \\
\left(\mathrm{g} \mathrm{day}^{-1}\right)\end{array}$ & $\begin{array}{c}\text { Energy } \\
\text { density } \\
\left(\mathrm{kcal} \mathrm{g}^{-1}\right)\end{array}$ \\
\hline \multicolumn{4}{|l|}{ Men } \\
\hline Full-fat yoghurt & $2526.5 \pm 601.5$ & $1570.4 \pm 377.5$ & $1.6 \pm 0.2$ \\
\hline Low-fat yoghurt & $2561.7 \pm 722.8$ & $1749.4 \pm 478.0^{*}$ & $1.5 \pm 0.3^{\star \star}$ \\
\hline \multicolumn{4}{|c|}{ Women } \\
\hline Full-fat yoghurt & $1926.6 \pm 461.1$ & $1351.1 \pm 335.2$ & $1.5 \pm 0.3$ \\
\hline Low-fat yoghurt & $1634.6 \pm 422.5^{\star *}$ & $1366.9 \pm 322.2$ & $1.2 \pm 0.3^{* \star *}$ \\
\hline
\end{tabular}

Dairy products are an important dietary source of some micronutrients such as calcium, potassium, phosphorus and vitamin $\mathrm{B}_{2}$. When we compared the intakes of these micronutrients between high and low consumers of yoghurt (Table 2) we found that, in general, there were no significant differences between both levels of yoghurt consumption, except in the group of men aged 20-34 years and in boys aged 4-9 years. There are not many descriptive studies comparing the nutritional differences between high and low consumers of yoghurt. In another work carried out in young adults ${ }^{27}$, the authors observed that the intakes of calcium, riboflavin and other micronutrients were significantly higher in high consumers of yoghurt. However, in that study the high consumption was linked to higher intakes of other dairy products (which are also rich in these micronutrients), while in our study there were no differences in the intake of milk or cheese between both groups of yoghurt consumption.

One remarkable fact is the low calcium intake in our population, quite below the Dietary Reference Intakes in some age and sex groups.

The balance between ED and food intake of the diet is considered an essential mechanism in the relationship between the individual and his/her energy needs ${ }^{28,29}$. However, the progressive increase in ED of the diet observed in Western societies has been considered as a risk factor for obesity ${ }^{30}$. When we analysed these variables in our sample, we found (Table 3) that the level of consumption (i.e. being either a high or a low consumer) did not significantly affect the food intake or the ED of the diet. The dynamics of these groups with age were similar to those of the general population ${ }^{29}$, so food intake did not change significantly in puberty or adulthood; ED, on the other hand, increased until post puberty and then decreased, a trend that was more noticeable in men than in women.

As with ED and food intake, macronutrient balance that is to say, the percentage of total energy intake provided by each macronutrient - did not change significantly between LC and HC males (Fig. 1). In 
Table 5 Distribution of socio-economic and educational levels among high and low consumers of different dairy products (percentage of the population belonging to each group)

\begin{tabular}{|c|c|c|c|c|c|c|c|c|}
\hline & \multicolumn{4}{|c|}{ Socio-economic level } & \multicolumn{4}{|c|}{ Educational level } \\
\hline & Low & Medium & High & $\chi^{2}, P$-value & Low & Medium & High & $\chi^{2}, P$-value \\
\hline \multicolumn{9}{|l|}{ Milk } \\
\hline Low consumers & 6.8 & 78.3 & 14.9 & $6.005,0.050$ & 12.8 & 65.1 & 22.1 & $0.654,0.721$ \\
\hline High consumers & 9.3 & 82.6 & 8.1 & & 12.8 & 62.0 & 25.2 & \\
\hline \multicolumn{9}{|c|}{ Yoghurts and desserts } \\
\hline Low consumers & 7.7 & 83.6 & 8.8 & $1.485,0.476$ & 14.0 & 66.9 & 19.1 & $6.297,0.043$ \\
\hline High consumers & 9.5 & 79.4 & 11.1 & & 12.0 & 59.5 & 28.5 & \\
\hline \multicolumn{9}{|l|}{ Cheese } \\
\hline Low consumers & 7.8 & 82.0 & 10.2 & $0.534,0.766$ & 14.0 & 65.3 & 20.7 & $1.638,0.441$ \\
\hline High consumers & 9.7 & 80.3 & 10.1 & & 14.7 & 60.1 & 25.2 & \\
\hline
\end{tabular}

women, on the contrary, we observed a difference in macronutrient balance: the percentage of energy provided by lipids was lower among those who consumed more yoghurt (Fig. 2). This phenomenon, which may seem paradoxical, may be explained by the high percentage of women in the HC group who ate low-fat products $31.1 \%$, vs. $19.8 \%$ of males). This dietary behaviour in women HC was connected to other habits such as drinking skimmed milk or consuming fewer sugars and cereals (Fig. 3), which were not found in men HC of yoghurt (data not shown). These findings support the existence of a balancing mechanism within the diet as a whole that compensates the variation in intakes of some foods with intakes of others, resulting in a similar macronutrient balance. However, the balancing mechanism can be insufficient when the substitution affects several food groups, as in the case of women consumers of low-fat dairy products in our study or in the case of the displacement of nutrient-rich foods by energy-dense, nutrient-poor foods in the diet observed by Kant ${ }^{31}$. In these cases, the dietary pattern resulted in changes in the energy and macronutrient intakes. It should be borne in mind that fermented dairy product desserts alone represent a relatively minor component of the $\mathrm{diet}^{3}$.

The difference observed between sexes regarding macronutrient balance led us to analyse the ED and food intake of the subgroup of high consumers of low-fat dairy products, both in men and women. The data obtained indicated the existence of a compensatory mechanism between ED and volume in men, resulting in an adequate energy intake (Table 4). As high consumers of low-fat yoghurts had lower ED, they compensated with greater volume. This behaviour has been described in other circumstances, for instance in diets in developing countries and in therapeutic diets ${ }^{32,33}$. Nevertheless, the capacity to combine the two variables to achieve a certain energy intake does have some limits. In this group of women, for example, the consumption of low-fat fermented dairy products, in conjunction with other dietary habits (Fig. 3), led to a diet with low ED that was not compensated for by an increase in volume. This meant that there was a significant difference in energy intake between these women and the women who consumed full-fat yoghurt (Table 4).

The fact that the balancing mechanisms were so clear in men and not in women suggests that this behaviour may be conscious. We appear to have found an example of a dietary attitude that is the result of the impact of a cultural change (the popularity of low-calorie foods) which, particularly in women, leads to a tendency to consume low-fat yoghurt within the framework of a wider change in the diet. This change varies nutritional parameters that have, otherwise, remained stable in the general population in the past decades ${ }^{3}$.

In the population studied, $28.5 \%$ of those of high educational level were high consumers of yoghurt and $19.1 \%$ were low consumers $(P<0.05)$ (Table 5$)$; however, no significant differences were observed in the distribution according to socio-economic level. On the other hand, we found no correlation between the intake of yoghurt and the consumption of other dairy products such as milk or cheese; that is to say, the intake of this foodstuff was independent of the consumption of other dairy products outside the category of probiotics.

In our opinion, these two findings indicate that our population sees yoghurt as a food with a specific role in the diet. The results are an indication of the influence of the change in attitudes towards diet and its role in health that has taken place in our society in recent years. They also indicate that, although purchasing power does not determine a greater consumption of these products, a higher educational level may be associated with a greater awareness of their benefits.

Finally, further investigation is required to assess the effects of these phenomena on body composition because, in recent years, different studies have found a protective effect of increased calcium intake against obesity via a sequence of steps that leads to an inhibition of fatty acid synthase and an increase in lipolytic activity $^{11-13,34}$. Interestingly, these anti-obesity effects are greater with dairy sources of calcium than with calcium carbonate ${ }^{11,34}$. In our study we did not find a correlation between intake of yoghurt and body mass index, but this could be due to the fact that there are many other factors 
involved in body composition that we did not contemplate in our study.

\section{Conclusions}

A higher consumption of yoghurt and other fermented dairy product desserts did not lead to significant differences in energy intake or macronutrient balance compared with the group of low consumers. This suggests that there is a biological mechanism that compensates for the consumption of different groups of food and allows the overall intakes of nutrients to remain stable. Energy intake and macronutrient balance were only modified in women in the high consumption group, among whom a considerable number consumed low-fat products. However, this difference was not due exclusively to the consumption of dairy products but took place within a context of other changes in the diet.

There is a relationship between high consumption of yoghurt and higher educational level, which could be due to a greater awareness of the relationship between diet (and, in particular, functional foods) and health in this sector of the population.

\section{Acknowledgements}

This paper is dedicated to the memory of Professor Carles Martí-Henneberg. The study was partially funded by a grant from Danone SA Spain.

\section{References}

1 Martí-Henneberg C, Arija V, Cucó G, Fernández-Ballart J. Evolution of nutritional impact produced by milk and dairy products intake in Spain. In: Serrano-Ríos M, ed. Dairy Products in Human Health and Nutrition. Rotterdam: Balkema Publishers, 1994; 121-7.

2 Ministerio de Agricultura, Pesca y Alimentación. Secretaría General de Agricultura y Alimentación. Dirección General de Alimentación (MAPA). La Alimentación en España 1998. Madrid: Industrias Gráficas CARO SL, 1999.

3 Capdevila F, Llop D, Guillén N, Luque V, Pérez S, Sellés V, et al. Consumo, hábitos alimentarios y estado nutricional de la población de Reus (X): evolución de la ingestión alimentaria y de la contribución de los macronutrientes al aporte energético (1983-1999), según edad y sexo. Med. Clin. (Barc.) 2000; 115: 7-14.

4 Moreno LA, Sarria A, Popkin BM. The nutrition transition in Spain: a European Mediterranean country. Eur.J. Clin. Nutr. 2002; 56(10): 992-1003.

5 Young J. European market developments in prebiotic- and probiotic-containing foodstuffs. Br. J. Nutr. 1998; 80(Suppl. 2): S231-3.

6 Aranceta J, Pérez C, Serra LI. Disponibilidad y consumo de probióticos en España. In: Ortega RM, Marcos A, Aranceta J, Mateos JA, Requejo AM, Serra LI, eds. Alimentos Funcionales, Probióticos. Madrid: Editorial Médica Panamericana SA, 2002; 19-31.

7 Diplock AT, Aggett PJ, Ashwell M, Bornet F, Fern EB, Roberfroid M. Scientific concepts of functional foods in Europe: consensus document. Br.J. Nutr. 1999; 81(Suppl. 1): S5-27.
8 Bissonnette DJ, Jeejeebhoy KN. Meeting dietary nutrient requirements with cow's milk and milk products. In: SerranoRíos M, ed. Dairy Products in Human Health and Nutrition. Rotterdam: Balkema Publishers, 1994; 31-52.

9 Teegarden D, Lyle RM, Proulx WR, Johnston CC, Weaver CM. Previous milk consumption is associated with greater bone density in young women. Am. J. Clin. Nutr. 1999; 69: 1014-7.

10 Jensen RG. The importance of milk and milk products in the diet. In: Miller GD, Jarvis JK, McBean LD, eds. Handbook of Dairy Foods and Nutrition. Boca Raton, FL: CRC Press, 2000; $4-28$.

11 Zemel MB, Shi H, Greer B, DiRienzo D, Zemel PC. Regulation of adiposity by dietary calcium. FASEB J. 2000; 14: $1132-8$.

12 Carruth BR, Skinner JD. The role of dietary calcium and other nutrients in moderating body fat in preschool children. Int J. Obes. 2001; 25: 559-66.

13 Heaney RP, Davies KM, Barger-Lux MJ. Calcium and weight: clinical studies. J. Am. Coll. Nutr. 2002; 21(Suppl. 2): S152-5.

14 Miller GD, DiRienzo DD, Reusser ME, McCarron DA. Benefits of dairy product consumption on blood pressure in humans: a summary of the biomedical literature. J. Am. Coll. Nutr. 2000; 19(Suppl. 2): S147-64.

15 Massey LK. Dairy food consumption, blood pressure and stroke. J. Nutr. 2001; 131: 1875-8.

16 Appel LJ, Moore TJ, Ozarzanek E, Vollmer WM, Svetkey LP, Sacks FM, et al. A clinical trial of the effects of dietary patterns on blood pressure. N. Engl. J. Med. 1997; 336: $1117-24$.

17 Elbon SM, Johnson MA, Fischer JG. Developing an instrument to measure the influence of knowledge, behaviours and attitudes on milk consumption patterns in older participants of a community wellness group: a pilot study. J. Nutr. Elderly 1996; 15: 21-37.

18 Hitchins AD, McDonough FE. Prophylactic and therapeutic aspects of fermented milk. Am. J. Clin. Nutr. 1989; 49: 675-84.

19 Rambaud JC, Bouhnik Y, Marteau PH. Dairy products and intestinal flora. In: Serrano-Ríos M, ed. Dairy Products in Human Health and Nutrition. Rotterdam: Balkema Publishers, 1994; 389-99.

20 Goldin BR. Health benefits of probiotics. Br. J. Nutr. 1998; 80(Suppl. 2): S203-7.

21 Palou A, Serra F. Perspectivas europeas sobre los alimentos funcionales. Alimentación Nutrición y Salud 2000; 7: 76-90.

22 Stanton C, Gardiner G, Meehan H, Collins K, Fitzgerald G, Lynch PB, Ross RP. Market potential for probiotics. Am. J. Clin. Nutr. 2001; 73(Suppl. 2): S476-83.

23 Stuff JE, Garza C, O’Brian-Smith E, Nichols BL, Montandon $\mathrm{CM}$. A comparison of dietary methods in nutritional studies. Am. J. Clin. Nutr. 1983; 37: 300-6.

24 Favier JC, Ireland-Ripert J, Toque C, Feinberg M. Répertoire général des aliments. Table de composition. Paris: TEC \& DOC Lavoisier-INRA, 1977.

25 Mataix-Verdú J, Mañas M, Llopis J, Martínez E. Tabla de Composición de Alimentos Españoles, 2nd ed. Granada: Ciencias de la Salud, Monográfica Universidad de Granada, 1995.

26 SPSS, Inc. SPSS 10.0. Manual del Usuario. Chicago, IL: SPSS, Inc., 1999.

27 Ortega RM, Requejo AM, López AM, Navia B. Repercusión del consumo de probióticos en el estado nutricional. In: Ortega RM, Marcos A, Aranceta J, Mateos JA, Requejo AM, Serra LI, eds. Alimentos Funcionales, Probióticos. Madrid: Editorial Médica Panamericana SA, 2002; 77-87.

28 Fomon SJ, Filer LJ, Ziegler EE, Bergmann KE, Bergmann RL. Skim milk in infant feeding. Acta Pediatr. Scand. 1977; 66: $17-30$. 
29 Martí-Henneberg C, Capdevila F, Arija V, Pérez S, Cucó G Vizmanos B, et al. Energy density of the diet, food intake and energy intake by age and sex in a healthy population. Eur. J. Clin. Nutr. 1999; 53: 421-8.

30 Rolls BJ, Bell EA, Castellanos VH, Chow M, Pelkman C, Thorwart ML. Energy density but not fat content of food affected energy intake in lean and obese women. Am.J. Clin. Nutr. 1999; 69: 863-7.

31 Kant AK. Consumption of energy-dense, nutrient-poor foods by adult Americans: nutritional and health implications. The Third National Health and Nutrition Examination Survey, 1988-1994. Am. J. Clin. Nutr. 2000; 72: 929-36.
32 Michaelsen KF, Jorgensen MH. Dietary fat content and energy density during infancy and childhood; the effect on energy intake and growth. Eur. J. Clin. Nutr. 1995; 49: $467-83$.

33 Brown KH, Sánchez-Griñán $\mathrm{M}$, Pérez $\mathrm{F}$, Peerson JM, Ganoza L, Stern JS. Effects of dietary energy density and feeding frequency on total daily energy intakes of recovering malnourished children. Am. J. Clin. Nutr. 1995; 62: 13-18.

34 Zemel MB. Regulation of adiposity and obesity risk by dietary calcium: mechanisms and implications. J. Am. Coll. Nutr. 2002; 21(Suppl. 2): S146-51. 